\title{
EVALUASI SISTEM PENGENDALIAN INTERN PEMERINTAH ATAS PELAYANAN PERIZINAN PADA DINAS PENANAMAN MODAL DAN PELAYANAN TERPADU SATU PINTU DAERAH PROVINSI SULAWESI UTARA
}

\author{
Magfirah Rahman ${ }^{1}$, Grace B. Nangoi ${ }^{2}$, Stanley Kho Walandouw ${ }^{2}$ \\ ${ }^{1,2}$ Jurusan Akuntansi, Fakultas Ekonomi dan Bisnis, Universitas Sam Ratulangi, Jl. Kampus Bahu, Manado, \\ 95115, Indonesia \\ ${ }^{1}$ E-mail: magfirahrahman@gmail.com
}

\begin{abstract}
Government in carry out public services such as licensing service or other services not escape the chances of risks, such as fraud and maladministration, then to minimize this risks, it takes an integral system that can control the implementation of service. Government Internal Control System (GICS) implementation whole in the central government and local government. GICS has an important role in the implementation of services by government agencies. The purpose of research was to evaluate internal control on licensing service in the Investment and One Stop Integrated Service Office of North Sulawesi based of Government Regulation Number 60 of 2008 regarding Government Internal Control System (GICS) consists of five components; control environment, risk assessment, control activities, information and communication and monitoring activities. The type of research used qualitative descriptive method. Data were collected by observation, interviews and documentation. The results showed that component of control activities which is physical asset was not in accordance with Government Regulation Number 60 of 2008, this difference because the security of assets was not running well. For other components, such as control environment, risk assessment, information and communication and monitoring activities, evaluation results indicate it was in accordance with Government Regulation Number 60 of 2008.
\end{abstract}

Keywords: evaluation; internal control; GICS; licensing service

\section{PENDAHULUAN}

Salah satu tugas pokok pemerintah yaitu memberikan pelayanan kepada masyarakat. Pelayanan yang diberikan berupa pelayanan publik, hal ini tercermin dari terbitnya UndangUndang Nomor 25 Tahun 2009 tentang Pelayanan Publik dan Peraturan Pemerintah Republik Indonesia Nomor 96 Tahun 2012 tentang Pelaksanaan Undang-Undang Nomor 25 Tahun 2009 tentang Pelayanan Publik. Pemerintah dituntut untuk memberikan pelayanan yang prima atau yang sebaik-baiknya dalam menyelenggarakan pelayanan publik kepada masyarakat, namun isu-isu yang berkembang dimasyarakat bahwa pelayanan publik identik dengan korupsi, kolusi dan nepotisme atau istilahnya maladministrasi. Menurut Ombudsman Republik Indonesia (2017) yang merupakan penyelenggara pengawasan atas pelayanan publik menyebutkan bahwa ciri-ciri maladministrasi yaitu pelayanan tidak sesuai urutan/mendahulukan pihak tertentu, pungutan diluar ketentuan, tidak ada tanda terima atas pembayaran, memperpanjang/memperpendek prosedur, penyelesaian layanan tidak tepat waktu, persyaratan pelayanan tidak jelas/tidak sesuai ketentuan.

Pelayanan perizinan merupakan salah satu bentuk pelayanan publik yang diselenggarakan oleh pemerintah berupa pelayanan administratif. Pelayanan perizinan juga tidak lepas dengan adanya isu maladministrasi. Ombudsman Republik Indonesia (2019) dari laporan pengaduan masyarakat menjelaskan bahwa persoalan terkait dengan penerbitan izin 
adalah lamanya pengurusan, kualitas Sumber Daya Manusia (SDM) pelaksana teknis kurang memadai dan sistem perizinan bertahap/berlapis, yang dimaksud dengan sistem perizinan berlapis yaitu permohonan sebuah izin akan menjadi prasyarat izin yang lain karena pengajuan izin harus melewati beberapa institusi atau lembaga sehingga cenderung berbelit, panjang dan menghabiskan biaya yang cukup besar.

Pemerintah dalam melaksanakan pelayanan publik baik itu pelayanan perizinan maupun bentuk pelayanan lainnya tidak lepas dari kemungkinan terjadinya risiko seperti kecurangan dan maladministrasi, maka untuk meminimalisir risiko-risiko ini dibutuhkan sebuah sistem yang integral yang dapat mengontrol atau mengawasi jalannya pelaksanaan pelayanan. Menurut Sujarweni (2015a:69), sistem pengendalian internal adalah suatu sistem yang dibuat untuk memberi jaminan keamanan bagi unsur-unsur yang ada dalam perusahaan. Sejalan dengan hal ini pemerintah telah menerbitkan peraturan tentang ketentuan penerapan pengendalian internal yaitu Peraturan Pemerintah Nomor 60 Tahun 2008 tentang Sistem Pengendalian Intern Pemerintah (SPIP). SPIP memiliki peranan penting dalam pelaksanaan pelayanan yang dilakukan oleh instansi pemerintah. Penelitian yang dilakukan oleh Nurbaeti (2019) menunjukkan bahwa SPIP berpengaruh secara signifikan terhadap pelayanan publik. Hal ini senada dengan penelitian yang dilakukan oleh Tadeko (2017) yang menyatakan bahwa terdapat pengaruh simultan lingkungan pengendalian, penilaian risiko, kegiatan pengendalian, informasi dan komunikasi serta pemantauan terhadap kualitas pelayanan SKPD Kabupaten Banggai.

Dinas Penanaman Modal dan Pelayanan Terpadu Satu Pintu (DPMPTSP) Daerah Provinsi Sulawesi Utara dalam memberikan pelayanan yang berkualitas harus menjalankan SPIP yang sesuai dengan aturan yang berlaku yaitu Peraturan Pemerintah Nomor 60 Tahun 2008 tentang Sistem Pengendalian Intern Pemerintah. DPMPTSP tidak terlepas dari adanya kemungkinan terjadinya risiko-risiko seperti dugaan kecurangan dan maladministrasi. Berdasarkan Indeks Persepsi Maladminitrasi (Inperma) Tahun 2019 oleh Ombudsman RI menunjukkan bahwa indeks persepsi maladminitrasi pada layanan perizinan di Sulawesi Utara berada dilevel maladministrasi rendah dengan skor 4,09, seperti terlihat pada tabel berikut :

\section{Tabel 1. Sebaran Indeks Persepsi Maladministrasi pada Layanan Perizinan}

\begin{tabular}{clc}
\hline No & \multicolumn{1}{c}{ Provinsi } & Indeks Persepsi Maladministrasi \\
\hline 1 & Aceh & 4,64 \\
2 & Kalimantan Utara & 4,63 \\
3 & Maluku & 4,61 \\
4 & Gorontalo & 4,40 \\
5 & NTB & 4,38 \\
6 & Sulawesi Tengah & 4,27 \\
7 & Papua & 4,16 \\
8 & Sulawesi Utara & 4,09 \\
9 & Maluku Utara & 3,97 \\
10 & D.I Yogyakarta & 3,73 \\
\hline
\end{tabular}

Keterangan :

1. $\leq 4,50$ Maladministrasi Rendah

2. 4,51-5,50 Maladminitrasi Sedang menuju Rendah

3. 5,51-6,50 Maladministrasi Sedang menuju Tinggi

4. $\geq 6,51$ Maladmintrasi Tinggi

(Sumber : Inperma Ombudsman RI, 2019) 
Berdasarkan tabel tersebut terlihat bahwa Sulawesi Utara berada dilevel maladministrasi rendah, namun bukan berarti bebas dari adanya dugaan maladminitrasi, dengan demikian adanya kemungkinan indikasi ketidaksesuaian antara pelayanan yang diberikan dengan pelayanan yang diterima masyarakat. Atas dasar fenomena-fenomena tersebut, perlu dibahas dan dikaji lebih lanjut mengenai pelaksanaan sistem pengendalian intern pemerintah atas pelayanan perizinan pada DPMPTSP Daerah Provinsi Sulawesi Utara dengan berlandaskan Peraturan Pemerintah Nomor 60 Tahun 2008 tentang SistemPengendalian Intern Pemerintah.

\section{TINJAUAN PUSTAKA}

Konsep Akuntansi Pemerintahan. Sujarweni (2015b:18) menyatakan bahwa akuntansi pemerintahan adalah akuntansi yang bersangkutan dengan bidang keuangan negara, dari anggaran sampai dengan pelaksanaan dan pelaporannya, termasuk segala pengaruh yang ditimbulkannya. Erlina et al., (2015:2), menyatakan bahwa akuntansi pemerintahan adalah akuntansi yang digunakan untuk memberi informasi mengenai transaksi ekonomi dan keuangan pemerintah kepada pihak eksekutif, legislatif, yudikatif dan masyarakat.

Tujuan Akuntansi Pemerintahan. Hasanah dan Fauzi (2017:2) menyatakan bahwa tujuan akuntansi pemerintahan yaitu sebagai berikut :

1. Akuntabilitas. Fungsi akuntabilitas lebih luas dari sekedar ketaatan kepada peraturan perundang-undangan yang berlaku, tetapi tetap memperhatikan penggunaan sumber daya secara bijaksana, efisien, efektif dan ekonomis. Tujuan utama akuntabilitas ditekankan kepada setiap pengelola atau manajemen dapat menyampaikan akuntabilitas keuangan dengan menyampaikan laporan keuangan.

2. Manajerial. Akuntansi pemerintah memungkinkan pemerintah untuk melaksanakan fungsi manajerial dengan melakukan perencanaan berupa penyusunan APBN dan strategi pembangunan lain.

3. Pengawasan. Akuntansi pemerintahan dibuat untuk memungkinkan diadakannya pengawasan pengurusan keuangan negara dengan lebih mudah oleh aparat pemeriksa seperti BPK-RI.

Sistem Pengendalian Internal. Mulyadi (2016:129) menyatakan bahwa sistem pengendalian internal meliputi struktur organisasi, metode dan ukuran-ukuran yang digabungkan untuk melindungi aset organisasi, memeriksa ketelitian dan keandalan data akuntansi, mendorong efisiensi dan mendorong dipatuhinya kebijakan manajemen. Pengendalian internal disebut juga sebuah kerangka kerja terintegrasi adalah sebuah standar yang digunakan perusahaan dalam mendesain, menganalisis, dan mengevaluasi pengendalian internal (Warren et al., 2015:400). Menurut Sujarweni (2015a:69), sistem pengendalian internal adalah suatu sistem yang dibuat untuk memberi jaminan keamanan bagi unsur-unsur yang ada dalam perusahaan.

Tujuan Sistem Pengendalian Internal. Menurut Sujarweni (2015a:69), tujuan perusahaan membuat sistem pengendalian internal adalah sebagai berikut : 1) untuk menjaga kekayaan organisasi, 2) untuk menjaga keakuratan laporan keuangan perusahaan, 3) untuk menjaga kelancaran operasi perusahaan, 4) untuk menjaga kedisiplinan dipatuhinya kebijakan manajemen, dan 5) agar semua lapisan yang ada di perusahaan tunduk pada hukum dan aturan yang sudah ditetapkan di perusahaan. Menurut Tuanakotta (2015:94), tujuan dari pengendalian internal secara garis besar dapat dibagi ke dalam empat kelompok yaitu: 1) tujuan strategis, dimana dengan sasaran-sasaran utama yang mendukung misi entitas, 2) tujuan pelaporan keuangan, agar laporan keuangan bebas dari salah saji material, tepat waktu dan tepat guna, 3) tujuan operasional, dimana pengendalian mengamankan operasi entitas 
yang dikenal sebagai operasional kontrol dan 4) tujuan kepatuhan, terhadap hukum dan ketentuan perundang-undangan.

Sistem Pengendalian Intern Pemerintah. Menurut Peraturan Pemerintah Nomor 60 Tahun 2008 tentang Sistem Pengendalian Intern Pemerintah, bahwa sistem pengendalian intern pemerintah adalah proses yang integral pada tindakan dan kegiatan yang dilakukan secara terus-menerus oleh pimpinan dan seluruh pegawai untuk memberikan keyakinan memadai atas tercapainya tujuan organisasi melalui kegiatan yang efektif dan efisien, keandalan pelaporan keuangan, pengamanan aset negara dan ketaatan terhadap peraturan perundang-undangan.

Unsur-unsur Sistem Pengendalian Intern Pemerintah. Berdasarkan Peraturan Pemerintah Nomor 60 Tahun 2008 tentang Sistem Pengendalian Intern Pemerintah, sebagai berikut :

1. Lingkungan pengendalian. Pimpinan instansi pemerintah wajib menciptakan dan memelihara lingkungan pengendalian yang menimbulkan perilaku positif dan kondusif untuk penerapan sistem pengendalian intern dalam lingkungan kerjanya, melalui : a) penegakan integritas dan nilai etika, b) komitmen terhadap kompetensi, c) kepemimpinan yang kondusif, d) pembentukan struktur organisasi yang sesuai dengan kebutuhan, e) pendelegasian wewenang dan tanggung jawab yang tepat, f) penyusunan dan penerapan kebijakan yang sehat tentang pembinaan sumber daya manusia, g) perwujudan peran aparat pengawasan intern pemerintah yang efektif, dan h) hubungan kerja yang baik dengan instansi pemerintah terkait.

2. Penilaian risiko. Penilaian risiko terdiri atas : a) identifikasi risiko dan b) analisis risiko.

3. Kegiatan pengendalian. Terdiri atas : a) reviu atas kinerja instansi pemerintah yang bersangkutan, b) pembinaan sumber daya manusia, c) pengendalian atas pengelolaan sistem informasi, d) pengendalian fisik atas aset, e) penetapan dan reviu atas indikator dan ukuran kinerja, f) pemisahan fungsi, g) otorisasi atas transaksi dan kejadian penting, h) pencatatan yang akurat dan tepat waktu atas transaksi dan kejadian, i) pembatasan akses atas sumber daya dan pencatatannya, $\mathrm{j}$ ) akuntabilitas terhadap sumber daya dan pencatatannya, dan k) dokumentasi yang baik atas sistem pengendalian intern serta transaksi dan kejadian penting.

4. Informasi dan komunikasi. Untuk menyelenggarakan komunikasi yang efektif sebagaimana, pimpinan instansi pemerintah harus sekurang-kurangnya : a) menyediakan dan memanfaatkan berbagai bentuk dan sarana komunikasi, b) Mengelola, mengembangkan, dan memperbaharui sistem informasi secara terus menerus.

5. Pemantauan pengendalian intern. Pimpinan instansi pemerintah wajib melakukan pemantauan sistem pengendalian intern. Pemantauan sistem pengendalian intern dilaksanakan melalui : a) pemantauan berkelanjutan, b) evaluasi terpisah, dan c) tindak lanjut rekomendasi hasil audit dan reviu lainnya.

Pelayanan Publik. Menurut Peraturan Pemerintah Republik Indonesia Nomor 96 Tahun 2012 tentang Pelaksanaan UU Nomor 25 Tahun 2009 tentang Pelayanan Publik, menjelaskan bahwa pelayanan publik adalah kegiatan atau rangkaian kegiatan dalam rangka pemenuhan kebutuhan pelayanan sesuai dengan peraturan perundang-undangan bagi setiap warga negara dan penduduk atas barang, jasa dan/atau pelayanan administratif yang disediakan oleh penyelenggara pelayanan publik.

Ruang Lingkup Pelayanan Publik. Menurut Peraturan Pemerintah Republik Indonesia Nomor 96 Tahun 2012 tentang Pelaksanaan UU Nomor 25 Tahun 2009 tentang Pelayanan Publik, adapun ruang lingkup pelayanan publik sebagai berikut : 1) pelayanan barang publik, 2) pelayanan jasa publik, dan 3) pelayanan administratif. 
Pelayanan Perizinan. Menurut Peraturan Menteri Dalam Negeri Republik Indonesia Nomor 138 Tahun 2017 tentang Penyelenggaraan Pelayanan Terpadu Satu Pintu Daerah pengertian perizinan, yaitu pemberian dokumen dan bukti legalitas persetujuan dari pemerintah kepada seseorang atau pelaku usaha/kegiatan tertentu sesuai dengan ketentuan peraturan perundang-undangan. Menurut Peraturan Presiden Republik Indonesia Nomor 97 Tahun 2014 tentang Penyelenggaraan Pelayanan Terpadu Satu Pintu, perizinan adalah segala bentuk persetujuan yang dikeluarkan oleh pemerintah dan pemerintah daerah yang memiliki kewenangan sesuai dengan ketentuan peraturan perundang-undangan.

Mekanisme Pelayanan Perizinan. Berdasarkan Peraturan Menteri Dalam Negeri Republik Indonesia Nomor 138 Tahun 2017 tentang Penyelenggaraan Pelayanan Terpadu Satu Pintu Daerah, mekanisme pelayanan perizinan dengan tahapan paling sedikit meliputi:

1. Menerima dan memverifikasi berkas permohonan.

2. Memberikan tanda terima kepada pemohon.

3. Menolak permohonan izin dan/atau non izin yang tidak sesuai dengan ketentuan peraturan perundang-undangan.

4. Memproses dan menerbitkan dokumen izin dan/atau non izin.

5. Memproses pencabutan dan pembatalan dokumen izin dan/atau non izin.

6. Menyerahkan dokumen izin dan/atau non izin yang telah selesai kepada pemohon.

\section{METODE PENELITIAN}

Jenis penelitian yang digunakan yaitu deskriptif kualitatif. Penelitian ini berfokus pada pelaksanaan SPIP atas pelayanan perizinan di DPMPTSP Daerah Provinsi Sulawesi Utara. Penelitian dilakukan di Dinas Penanaman Modal dan Pelayanan Terpadu Satu Pintu (DPMPTSP) Daerah Provinsi Sulawesi Utara pada bulan Februari sampai dengan bulan April 2020. Jenis data yang digunakan dalam penelitian adalah data kualitatif. Sumber data dalam penelitian ini berupa data primer, yaitu data yang diperoleh langsung pada DPMPTSP Daerah Provinsi Sulawesi Utara. Metode pengumpulan data yang digunakan yaitu observasi, wawancara dan dokumentasi. Metode analisis yang digunakan dalam penelitian ini yaitu analisis deskriptif yang bertujuan untuk menguraikan, memberikan gambaran mengenai pelayanan perizinan yang dilaksanakan oleh DPMPTSP Daerah Provinsi Sulawesi Utara yang kemudian akan dievaluasi sistem pengendalian internalnya berdasarkan 5 unsur pengendalian menurut Peraturan Pemerintah Nomor 60 Tahun 2008. Pengujian keabsahan data (kredibilitas data) dilakukan dengan cara : 1) memperpanjang pengamatan, dan 2) triangulasi; triangulasi sumber dan waktu.

\section{HASIL PENELITIAN DAN PEMBAHASAN}

\subsection{Hasil penelitian}

Pelayanan Perizinan di DPMPTSP Daerah Provinsi Sulawesi Utara. Pelaksanaan pelayanan perizinan di DPMPTSP Daerah Provinsi Sulawesi Utara mengacu pada Peraturan Menteri Dalam Negeri Republik Indonesia Nomor 138 Tahun 2017 tentang Penyelenggaraan Pelayanan Terpadu Satu Pintu Daerah dan diatur lebih lanjut di dalam Peraturan Gubernur Nomor 5 Tahun 2018 tentang Pendelegasian Wewenang Perizinan dan Non perizinan kepada Dinas Penanaman Modal dan Pelayanan Terpadu Satu Pintu Daerah Provinsi Sulawesi Utara. Adapun alur atau mekanisme pelayanan perizinan di DPMPTSP Daerah Provinsi Sulawesi Utara, sebagai berikut:

1. Dimulai dari pemohon selaku pelaku usaha atau pihak ketiga yang diamanatkan dengan surat kuasa dari pelaku usaha melakukan pengajuan perizinan dengan menyiapkan segala dokumen/berkas yang diperlukan ke bagian front office. 
2. Pegawai front office melakukan verifikasi terhadap berkas tersebut, jika dokumen sudah lengkap dan sesuai kemudian akan diproses ke bagian selanjutnya namun jika berkas permohonan dari pelaku usaha tidak lengkap, berkas akan dikembalikan.

3. Berkas yang lengkap tadi, akan diproses dibagian back office dan akan dilakukan peninjauan lapangan oleh tim teknis. Peninjauan lapangan dilakukan untuk memeriksa apakah usaha tersebut telah sesuai dengan syarat dan ketentuan peraturan perundangundangan yang berlaku, jika sesuai berkas akan diproses untuk kemudian di terbitkan izinnya namun jika tidak sesuai berkas akan dikembalikan ke pelaku usaha.

4. Setelah izin diterbitkan, izin tersebut diserahkan ke Kepala Seksi untuk kemudian akan diperiksa dan divalidasi.

5. Selanjutnya izin tersebut diserahkan ke Kepala Bidang Perizinan untuk diperiksa dan divalidasi kembali.

6. Setelah selesai dari bagian back office, izin kemudian diserahkan ke Kepala Dinas untuk diperiksa kembali, jika telah selesai Kepala Dinas kemudian menandatangani dokumen izin tersebut.

7. Selanjutnya dokumen izin diserahkan kembali ke front office untuk kemudian diserahkan ke pelaku usaha. Jangka waktu pelayanan ditetapkan paling lama 5 hari kerja terhitung sejak diterimanya dokumen izin secara lengkap dan benar, serta dalam pelaksanaan pelayanan perizinan tidak dipungut biaya.

Pelaksanaan Sistem Pengendalian Intern Pemerintah atas Pelayanan Perizinan di DPMPTSP Daerah Provinsi Sulawesi Utara. Adapun pelaksanaan Sistem Pengendalian Intern Pemerintah atas pelayanan perizinan yang dilaksanakan oleh DPMPTSP dengan berdasarkan 5 unsur dalam SPIP, yaitu sebagai berikut :

1. Lingkungan pengendalian. Secara keseluruhan dalam penyelenggaraan unsur lingkungan pengendalian telah dilaksanakan sesuai aturan. Penegakan integritas dan nilai etika atas pelayanan perizinan dilaksanakan sebagaimana mestinya, untuk penyusunan dan penerapan aturan perilaku pegawai, Kepala Bidang Perizinan mengatakan bahwa pada pelaksanaan pelayanan perizinan setiap pegawai pada prinsipnya mengacu pada kode etik penyelenggaraan tugas Pegawai Negeri Sipil (PNS), ada juga penerapan aturan perilaku yang diatur dalam lingkup DPMPTSP, sebagai contoh untuk pelayanan perizinan dipercayakan pada pegawai yang berintegritas tinggi yang telah dipastikan tidak meminta, menerima uang atau bentuk apapun yang tidak sesuai dengan aturan dibuktikan dengan adanya penandatangan pakta integritas. Pimpinan dalam hal ini Kepala Bidang Perizinan selalu berusaha memberikan teladan pada pelaksanaan aturan perilaku tersebut. Setiap hari Senin saat apel, dilakukan pembacaan pakta integritas pegawai. Selanjutnya jika ternyata kedapatan melakukan pelanggaran akan dikenai tindakan disiplin. Tindakan disiplin ini dapat berupa, teguran secara lisan, secara tertulis, teguran yang dikenakan sanksi contohnya pangkatnya tidak dinaikkan, ditangguhkan sementara atau bahkan sampai ke penghentian dengan tidak hormat. Setiap pegawai yang bertugas untuk pelayanan perizinan telah mengetahui uraian tugas dan fungsinya masing-masing, misalkan untuk pegawai front office (FO) tugasnya untuk melakukan verifikasi terhadap berkas permohonan dari pelaku usaha dan untuk penyusunan standar kompetensi telah dilakukan karena hal ini juga termasuk ke dalam SOP (Standar Operasional Prosedur) untuk pelaksanaan pelayanan perizinan. Selanjutnya dalam meningkatkan kompetensi pegawai, rutin dilakukan pelatihan dan bimbingan seperti bimbingan teknis dan diklat, kemudian dalam pemilihan pimpinan, setiap pimpinan yang dipilih telah memiliki kemampuan manajerial dan pengalaman teknis mengenai pelayanan perizinan. Kepala Bidang Perizinan selalu berkomunikasi secara intensif dengan pegawai-pegawainya baik itu pegawai front office, back office, maupun Kepala Seksi. Setiap pelaporan yang masuk 
berkaitan selalu direspon secara positif oleh kabid. Struktur organisasi telah dibentuk dan jumlah pegawai selalu disesuaikan dengan tugas dan tanggung jawabnya, hal ini sesuai dengan Peraturan Gubernur Nomor 68 Tahun 2018 tentang Kedudukan, Susunan Organisasi, Tugas dan Fungsi Serta Tata Kerja DPMPTSP Daerah Provinsi Sulawesi Utara dan selalu dilaksanakan evaluasi secara periodik terhadap struktur organisasi ini. Telah dilaksanakan pelimpahan wewenang dan tanggung jawab, hal ini sesuai dengan struktur organisasi yang telah dibentuk bahwa setiap pegawai memiliki tugas dan fungsinya masing-masing. Penerapan kebijakan tentang pembinaan sumber daya manusia telah dilaksanakan, sebagai contoh untuk penelusuran latar belakang calon pegawai dilakukan sejak awal saat proses rekrutmen Calon Pegawai Negeri Sipil (CPNS) dan ini merupakan kebijakan dari pemerintah pusat. Peran APIP dalam hal ini yaitu inspektorat telah dilaksanakan secara efektif. Inspektorat melakukan pengawasan terhadap pengendalian intern atas pelayanan perizinan. Dengan melakukan 2 kali kunjungan kerja dalam 1 tahun secara rutin untuk mengawasi bagaimana jalannya pelayanan perizinan ini. Selain itu, hubungan kerja telah terjalin dengan baik dengan instansi-instansi terkait, dijelaskan oleh kabid bahwa DPMPTSP selalu melaporkan perkembangan penanaman modal ke BKPM. BKPM juga selalu memberikan asistensi dalam hal bimbingan teknis, diklat dan update informasi terkait penanaman modal.

2. Penilaian risiko. Penetapan tujuan dituangkan dalam bentuk visi dan misi serta dalam rencana strategis (renstra), pada penyelenggaraan pelayanan perizinan ini, risiko-risiko yang paling mungkin terjadi yaitu risiko administrasi, namun pada risiko ini kebanyakan berasal dari eksternal yaitu dari pelaku usahanya sendiri. Risiko internal biasanya terjadi pada sistem informasi semisal terjadi gangguan jaringan atau server error. Risiko maladministrasi juga tidak menutup kemungkinan bisa terjadi, untuk itu salah satu langkah dari DPMPTSP yaitu membuka suatu layanan pengaduan untuk para pelaku usaha terkait dengan pelaksanaan pelayanan perizinan. Ditemukan juga adanya pengaduan mengenai keterlambatan waktu atau lamanya waktu penerbitan dokumen izin. Dijelaskan lebih lanjut oleh Kepala Seksi Pengaduan, bahwa lamanya waktu penerbitan izin bukan sepenuhnya salah dari DPMPTSP karena kebanyakan dari pelaku usaha yang pada saat mengajukan permohonan izin, memasukkan berkas yang tidak lengkap atau tidak sesuai. Sehingga kebijakan dari DPMPTSP yaitu mengembalikan berkas tersebut. Berkas harus lengkap sebelum kemudian akan diproses. Hal ini yang kemudian disimpulkan oleh pelaku usaha bahwa proses penerbitan izin memakan waktu yang lama. Selain itu, untuk risiko bermasalahnya wifi atau jaringan internet, maka langkah yang diambil DPMPTSP yaitu menghubungi pihak penyedia layanan (provider) untuk dilakukannya perbaikan terhadap jaringan internet yang bermasalah.

3. Kegiatan pengendalian. Kinerja dari DPMPTSP dituangkan didalam rencana strategis dan untuk pelaksanaan reviu dalam lingkup DPMPTSP dilakukan setiap bulan oleh Kepala Dinas untuk menilai sejauh mana kinerja DPMPTSP. Selanjutnya, selalu dikomunikasikan mengenai visi misi dari DPMPTSP, dapat dibuktikan bahwa setiap pagi dan sore saat apel selalu ada waktu pembinaan dari pejabat kepada ASN/seluruh pegawai selama 15 menit. Pegawai diingatkan mengenai visi misi, rencana strategis dari DPMPTSP serta kebijakan-kebijakan yang diterbitkan Gubernur. Pembinaan seperti bimtek kepada pegawai rutin dilaksanakan, contohnya diklat mengenai aplikasi Si Cantik dan OSS (Online Single Submission). Selain itu, pengendalian atas sistem informasi telah dilaksanakan, dibuktikan dengan adanya salah satu bidang yang dibentuk khusus untuk menangani sistem informasi yaitu Bidang Pengembangan dan Sistem Informasi. Pengendalian fisik atas aset tercermin dari adanya kebijakan inventarisasi aset, sebagai contoh dibuatnya daftar invetaris aset pada setiap ruangan dan adanya penggunaan cctv, 
namun dalam hal pengamanan terhadap aset belum sepenuhnya baik karena penggunaan cctv belum maksimal, hal ini karena belum semua ruangan dilengkapi cctv dan ada beberapa cctv yang ditemukan tidak berfungsi. Selain itu, security/satpam hanya terdapat dipintu depan, sedangkan dipintu bagian samping tidak ada pengawasan oleh security/satpam, sehingga siapa saja dapat dengan mudah masuk ke dalam kantor karena pengamanan yang kurang ketat. Pemisahan fungsi telah dilaksanakan, misalkan pada bagian front office tugasnya hanya untuk memverifikasi berkas permohonan dari pelaku usaha dan setiap pegawai melayani satu orang. Kemudian ada verifikator 1 yaitu tim teknis, verifikator 2 yaitu Kepala Seksi dan verifikator 3 yaitu Kepala Bidang. Kepala dinas sebagai yang menandatangani dokumen perizinan, jadi untuk pembagian tugasnya jelas. Saat penerbitan izin, dokumen izin hanya dapat dikatakan sah jika ditandatangani oleh Kepala Dinas. Izin hanya dapat dikeluarkan apabila telah diotorisasi oleh Kepala Dinas. Pencatatan kegiatan/aktivitas dilakukan secara akurat dan tepat, karena penggunaan sistem informasi yaitu Si Cantik. Jadi transaksi/data ini di record berdasarkan waktu. Telah dilaksanakan pembatasan akses dan adanya akuntabilitas atas sumber daya, sebagai contoh yang melakukan verifikasi terhadap berkas permohonan dari pelaku usaha hanya menjadi tanggung jawab dari bagian front office. Selanjutnya yang dapat melakukan peninjauan dilapangan hanya tim teknis serta yang dapat melakukan penandatanganan dokumen perizinan hanya menjadi wewenang dari Kepala Dinas. Dokumen perizinan disimpan/diarsip dengan 2 cara, yaitu secara digital yang disimpan dikomputer dan dengan cara manual yaitu disimpan dilemari yang telah disediakan. Arsip manual harus tetap ada sebagai bukti untuk DPMPTSP bahwa telah diterbitkannya izin tersebut. Untuk arsip manual ini, DPMPTSP mengarsip sebanyak 2 rangkap. Arsip ini tidak dapat diambil, kecuali diperintahkan oleh APIP atau kepolisian.

4. Informasi dan komunikasi. Berdasarkan wawancara yang dilakukan, diperoleh hasil bahwa dalam hal informasi dan komunikasi dilingkup pelayanan perizinan maupun DPMPTSP telah memanfaatkan berbagai bentuk dan sarana, seperti komunikasi melalui telepon dan daring (dalam jaringan). Adanya penggunaan media sosial whatsapp, e-mail, facebook dan website DPMPTSP serta sistem informasi untuk pelayanan perizinan seperti Si Cantik, dan Online Single Submission (OSS) yang digunakan oleh pelaku usaha terkait pengurusan izin. Selanjutnya sistem informasi yang digunakan berasal dari pemerintah pusat, sehingga untuk pembaharuannya selalu mengikuti dan sesuai dengan kebijakan pusat. Di DPMPTSP selalu mengupayakan menggunakan sistem informasi terbaru demi kelancaran proses pengurusan izin. Untuk proses pengurusan izin, DPMPTSP telah menggunakan sistem berbasis elektronik sebagai kemudahan untuk para pelaku usaha yang diharapkan untuk proses perizinan dapat dilakukan dimana saja tanpa perlu mendatangi DPMPTSP, namun pada kenyataan dilapangan masih banyak pelaku usaha yang belum paham bagaimana cara mengurus izin secara elektronik tersebut dan masih bergantung pada pelayanan secara langsung di DPMPTSP.

5. Pemantauan pengendalian intern. Pemantauan berkelanjutan dilaksanakan secara rutin oleh Kepala Dinas untuk memantau bagaimana jalannya pengendalian intern. Semua aktivitas atau kegiatan diperiksa dengan tiga tahapan, yang pertama diperiksa secara internal oleh bidang perizinan. Adanya self control dari masing-masing pejabat di DPMPTSP terlebih khusus bidang perizinan, jadi Kepala Seksi melakukan kontrol, Kepala Bidang serta Kepala Dinas juga melakukan kontrol. Selanjutnya pada tahapan kedua, dikontrol oleh inspektorat selaku Aparat Pengawasan Intern Pemerintah (APIP). Selanjutnya tahapan yang ketiga adalah Badan Pemeriksa Keuangan (BPK). Diluar dari 3 ini, ada juga yang sifatnya eksternal seperti Ombudsman RI yang menangani segala macam bentuk maladminitrasi yang terjadi. Evaluasi terpisah dilakukan oleh inspektorat 
dengan 2 kali kunjungan kerja dalam 1 tahun dan Badan Pemeriksa Keuangan (BPK) dengan 1 kali kunjungan kerja dalam 1 tahun untuk memeriksa pelaksanaan pengendalian intern berjalan dengan baik serta tindak lanjut atas evaluasi yang telah dilakukan dari masing-masing pihak yang berwenang.

\subsection{Pembahasan}

Evaluasi Sistem Pengendalian Intern Pemerintah atas Pelayanan Perizinan di DPMPTSP Daerah Provinsi Sulawesi Utara berdasarkan Peraturan Pemerintah Nomor 60 Tahun 2008. Evaluasi dilakukan untuk mengetahui sejauh mana penerapan SPIP atas pelayanan perizinan di DPMPTSP Daerah Provinsi Sulawesi Utara. Evaluasi pengendalian intern dilakukan berdasarkan 5 unsur dalam Peraturan Pemerintah Nomor 60 Tahun 2008 yaitu lingkungan pengendalian, penilaian risiko, kegiatan pengendalian, informasi dan komunikasi dan pemantauan pengendalian intern dengan menggunakan indikator sesuai, belum sesuai dan tidak sesuai. Penjelasan lebih lanjut mengenai indikator-indikator yang digunakan, sebagai berikut:

1. Sesuai, jika semua sub unsur dari tiap-tiap unsur pengendalian internal telah terpenuhi sesuai yang diatur dalam Peraturan Pemerintah Nomor 60 Tahun 2008.

2. Belum sesuai, jika hampir semua sub unsur dari tiap-tiap unsur pengendalian internal telah terpenuhi tetapi ada beberapa sub unsur yang belum terpenuhi sesuai yang diatur dalam Peraturan Pemerintah Nomor 60 Tahun 2008.

3. Tidak sesuai, jika semua sub unsur dari tiap-tiap unsur pengendalian internal tidak terpenuhi sesuai yang diatur dalam Peraturan Pemerintah Nomor 60 Tahun 2008.

Berikut hasil evaluasi terhadap Sistem Pengendalian Intern Pemerintah atas Pelayanan Perizinan pada Dinas Penanaman Modal dan Pelayanan Terpadu Satu Pintu Daerah Provinsi Sulawesi Utara berdasarkan pada 5 unsur, yaitu sebagai berikut:

1. Lingkungan pengendalian. Seluruh sub unsur dalam lingkungan pengendalian telah terpenuhi dan dilaksanakan sesuai dengan PP Nomor 60 Tahun 2008, dengan adanya penyusunan aturan perilaku dan adanya tindakan disiplin yang diberikan jika terjadi penyimpangan, komunikasi antar pegawai yang kondusif, respon yang positif oleh Kepala Bidang terhadap setiap permasalahan, pembentukan struktur organisasi dan pelimpahan tanggung jawab sesuai struktur organisasi yang telah dibentuk, rutin dilakukan pembinaan pegawai, peran aparat pengawasan yang efektif dan adanya hubungan kerja yang baik antara DPMPTSP dengan instansi-instansi terkait.

2. Penilaian risiko. Pada unsur penilaian risiko yang terdiri dari dua sub unsur telah dilaksanakan sesuai dengan PP Nomor 60 Tahun 2008, dengan dilaksanakannya identifikasi dan analisis risiko dengan cara mengenali risiko apa saja yang termasuk risiko internal maupun risiko eksternal dan bagaimana menangani risiko tersebut, namun demikian perlu ditelaah lebih lanjut serta adanya atensi mengenai risiko-risiko yang bersumber dari internal dan eksternal seperti kejadian-kejadian yang tak terduga misalnya bencana alam, kebakaran, adanya pencurian data dan kemungkinan komputer terserang malware atau virus dan sebagainya, hal ini dimaksud agar DPMPTSP dapat meminimalisir masalah-masalah yang muncul dikemudian hari.

3. Kegiatan pengendalian. Hampir seluruh sub unsur dalam kegiatan pengendalian telah dilaksanakan sesuai dengan PP Nomor 60 Tahun 2008, namun ada satu sub unsur yang belum sesuai yaitu pengendalian fisik atas aset karena dalam hal pengamanan terhadap aset belum sepenuhnya baik dan maksimal, sedangkan untuk sub unsur lain telah sesuai, seperti dilakukannya reviu sebulan sekali atas kinerja dari DPMPTSP, adanya pembinaan terhadap pegawai, pengendalian atas sistem informasi, pemisahan dan otorisasi transaksi dilakukan dengan baik, pencatatan dilakukan secara akurat dan tepat waktu karena adanya penggunaan sistem informasi, pembatasan akses dan akuntabilitas atas sumber daya telah 
dilaksanakan secara baik dengan adanya pemberian akses hanya kepada pihak yang diberi wewenang serta perlakuan terhadap dokumen telah dilaksanakan dengan baik dengan dilakukannya 2 cara pengarsipan yaitu arsip secara digital dan manual.

4. Informasi dan komunikasi. Unsur informasi dan komunikasi telah dilaksanakan sesuai dengan PP Nomor 60 Tahun 2008, hal ini terlihat dari adanya pemanfaatan berbagai bentuk dan sarana komunikasi, seperti komunikasi melalui telepon, media sosial dan website serta DPMPTSP dalam hal pelayanan perizinan selalu mengupayakan menggunakan sistem informasi terbaru, namun ada hal yang perlu digaris bawahi mengenai sistem informasi ini, karena DPMPTSP dalam memberikan pelayanan telah menggunakan sistem berbasis elektronik yang dimana sasaran utamanya agar para pelaku usaha memperoleh kemudahan dalam pengurusan izin tanpa perlu mengajukan permohonan secara langsung ke DPMPTSP, tetapi kenyataan yang didapati bahwa masih banyak pelaku usaha yang belum paham bagaimana cara mengoperasikan sistem ini. Sehingga tujuan yang diinginkan DPMPTSP terkait sistem informasi tidak tercapai dan tidak sesuai dengan yang diharapkan.

5. Pemantauan pengendalian intern. Ketiga sub unsur dalam pemantauan pengendalian intern telah dilaksanakan sesuai dengan PP Nomor 60 Tahun 2008, dilihat dari pemantauan berkelanjutan telah dilaksanakan secara rutin oleh Kepala Dinas, dan untuk evaluasi terhadap pengendalian intern dilakukan oleh inspektorat sebagai APIP dan BPK sebagai pihak eksternal. Selain itu, ada juga pemantauan yang dilakukan oleh Ombudsman RI serta tindak lanjut atas evaluasi yang telah dilakukan dari masing-masing pihak yang berwenang.

\section{KESIMPULAN DAN SARAN}

\subsection{Kesimpulan}

Berdasarkan hasil penelitian dan pembahasan mengenai sistem pengendalian intern pemerintah atas pelayanan perizinan di DPMPTSP Daerah Provinsi Sulawesi Utara yang berdasarkan 5 unsur pengendalian dalam Peraturan Pemerintah Nomor 60 Tahun 2008 disimpulkan bahwa:

1. Lingkungan pengendalian sudah sesuai dan dilaksanakan dengan baik, aturan perilaku diterapkan dengan baik, komunikasi yang kondusif antar pegawai, adanya pembentukan struktur organisasi dengan tugas dan wewenang yang sesuai dan selalu dilakukan pembinaan terhadap pegawai.

2. Penilaian risiko sudah sesuai dan dilaksanakan dengan baik, identifikasi dan analisis risiko baik itu internal maupun eksternal telah dilakukan beserta langkah yang diambil untuk penanganan terhadap risiko-risiko tersebut.

3. Kegiatan pengendalian belum sesuai dan belum dilaksanakan secara maksimal, hal ini karena pada satu sub unsur yaitu pengendalian atas aset yang keamanannya masih kurang memadai.

4. Informasi dan komunikasi sudah sesuai dan dilaksanakan dengan baik, berbagai bentuk dan sarana untuk berkomunikasi telah digunakan, penggunaaan sistem informasi dalam pelaksanaan pelayanan juga telah dilakukan sebagai upaya untuk mempermudah proses pelayanan perizinan.

5. Pemantauan pengendalian intern sudah sesuai dan dilaksanakan dengan baik, adanya pemantauan dan evaluasi yang dilaksanakan secara rutin, oleh DPMPTSP maupun dari APIP serta dari pihak eksternal seperti BPK. Selain itu pemantauan juga dilaksanakan oleh Ombudsman Republik Indonesia serta dilaksanakan tindak lanjut atas evaluasi yang telah dilakukan dari masing-masing pihak yang berwenang. 


\subsection{Saran}

Berdasarkan hasil penelitian dan pembahasan terlihat bahwa pelaksanaan sistem pengendalian intern pemerintah atas pelayanan perizinan sudah cukup baik dan sesuai, namun ada beberapa hal yang harus diperhatikan DPMPTSP Daerah Provinsi Sulawesi Utara, yaitu :

1. Perlu dilakukan perbaikan untuk unsur kegiatan pengendalian karena ditemukan adanya ketidaksesuaian pada salah satu sub unsur yaitu pengendalian fisik atas aset. Hal ini agar dapat meminimalisir terjadinya kecurangan dan maladministrasi pada pelayanan perizinan.

2. Sebaiknya DPMPTSP juga rutin memberikan bimbingan untuk penggunaan sistem informasi dalam proses pengurusan izin sehingga pelaku usaha dapat memahami cara penggunaan sistem informasi tersebut, karena kenyataan yang terjadi masih banyak pelaku usaha yang belum melek teknologi, dengan adanya bimbingan semacam ini tentu lebih mempermudah kerja DPMPTSP dalam pengurusan izin.

\section{DAFTAR PUSTAKA}

Erlina., Rambe, S., \& Rasdianto. (2015). Akuntansi keuangan daerah berbasis akrual. Jakarta: Salemba Empat.

Hasanah, N. \& Fauzi, A. (2017). Akuntansi pemerintahan. Bogor : In Media

Mulyadi. (2016). Sistem informasi akuntansi. Jakarta : Salemba Empat.

Nurbaeti, T. (2019). Pengaruh good governance dan sistem pengendalian intern pemerintah terhadap kinerja aparatur pemerintah daerah dan implikasinya pada pelayanan publik (studi kasus di Pemerintah Kabupaten Garut). Proceeding Industrial Research Workshop and National Seminar, 10(1), 1299-1311. https://jurnal.polban.ac.id/proceeding/article/view/1430

Ombudsman Republik Indonesia. (2017). Laporan tahunan 2017. Jakarta : Sekretariat Jenderal Ombudsman Republik Indonesia.

Ombudsman Republik Indonesia. (2019). Laporan tahunan 2019. Jakarta : Sekretariat Jenderal Ombudsman Republik Indonesia.

Ombudsman Republik Indonesia. (2019). Indeks persepsi maladministrasi 2019. Jakarta : Sekretariat Jenderal Ombudsman Republik Indonesia.

Peraturan Gubernur Sulawesi Utara Nomor 5 Tahun 2018 tentang Pendelegasian Wewenang Perizinan dan Non perizinan kepada Dinas Penanaman Modal dan Pelayanan Terpadu Satu Pintu Daerah Provinsi Sulawesi Utara. Berita Daerah Provinsi Sulawesi Utara Tahun 2018 Nomor 4. Manado.

Peraturan Menteri Dalam Negeri Republik Indonesia Nomor 138 Tahun 2017 tentang Penyelenggaraan Pelayanan Terpadu Satu Pintu Daerah. Berita Negara Republik Indonesia Tahun 2017 Nomor 1956. Jakarta.

Peraturan Pemerintah Nomor 60 Tahun 2008 tentang Sistem Pengendalian Intern Pemerintah. Lembaran Negara Republik Indonesia Tahun 2008 Nomor 127. Jakarta.

Peraturan Pemerintah Republik Indonesia Nomor 96 Tahun 2012 tentang Pelaksanaan UU Nomor 25 Tahun 2009 tentang Pelayanan Publik. Lembaran Negara Republik Indonesia Tahun 2012 Nomor 215. Jakarta.

Peraturan Presiden Republik Indonesia Nomor 97 Tahun 2014 tentang Penyelenggaraan Pelayanan Terpadu Satu Pintu. Lembaran Negara Republik Indonesia Tahun 2014 Nomor 221. Jakarta.

Sujarweni, V. W. (2015a). Sistem akuntansi. Yogyakarta : Pustaka Baru Press.

Sujarweni, V. W. (2015b). Akuntansi sektor publik. Yogyakarta : Pustaka Baru Press. 
Tadeko, N. (2017). Pengaruh sistem pengendalian intern pemerintah terhadap kualitas pelayanan pada satuan kerja perangkat daerah (survey pada Pemerintah Daerah Kabupaten Banggai). E-Jurnal Katalogis, 5(2), 104-115. http://jurnal.untad.ac.id/jurnal/index.php/Katalogis/article/view/8496

Tuanakotta, T. M. (2015). Audit kontemporer. Jakarta: Salemba Empat.

Warren, C. S., Reeve, J. M., \& Duchac, J. E. (2015). Pengantar akuntansi adaptasi Indonesia. Jakarta : Salemba Empat. 